Pobrane z czasopisma Annales L - Artes http://artes.annales.umcs.pl

Data: 26/04/2023 05:08:15
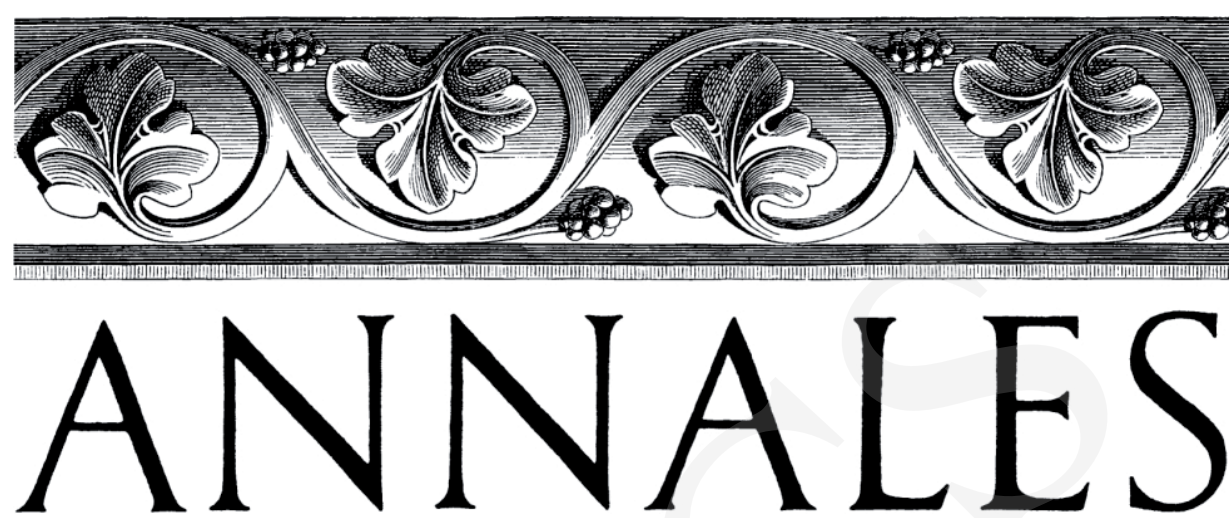

UNIVERSITATIS MARIAE CURIE-SKŁODOWSKA

SECTIO L

ARTES

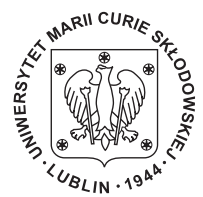

VOL. XVI, 1-2

2018

U N I W E R S Y T E T M A R I I C U R I E - S K Ł O D O W S K I E J I S S N $17322-1352$ 
A N N A LES

UNIVERSITATIS MARIAE CURIE-SKŁODOWSKA

LUBLIN - POLONIA

VOL. XVI, 1-2

SECTIO L

2018

\section{SPIS TREŚCI \\ TABle of Contents}

Pawee Sygowski

Na pograniczu wyznaniowym.

Nieistniejąca unicka cerkiew pod wezwaniem św. Praksedy

Męczennicy w Milejowie i jej wyposażenie

On the Religious Borderland. A Defunct Uniate Church under the

Invocation of St. Praxedes the Martyr in Milejów and its

Equipment

JERZY ŻYWICKI

Architekci międzywojennego Lublina. Przyczynek do

charakterystyki środowiska w pierwszym pięcioleciu

niepodległości (1918-1923)

The Architects of the Interwar Lublin. A Contribution to the

Description of Their Milieu in the First Five Years

of Independence (1918-1923)

Agata Kusto

Echa międzywojnia w muzycznym folklorze powojennej

Lubelszczyzny. Na podstawie zapisów Włodzimierza Dębskiego

63

Echoes of the Interwar Period in Music Folklore of Postwar

Lublin Province. On the Basis of Włodzimierz Dębski’s Notes

TOMASZ JASIŃSKI

Kolędy i pastorałki zapisane przez Jerzego Jasińskiego, organistę kościoła parafialnego w Łabuniach na Zamojszczyźnie

Christmas Carols and Pastorals written by Jerzy Jasiński, an Organist of the Parish Church in Łabunie in Zamość region 
Pobrane z czasopisma Annales L - Artes http://artes.annales.umcs.pl

Data: 26/04/2023 05:08:15

RAFAE RozMUS

Kolęda jako źródło inspiracji w twórczości kompozytorów

polskich w latach 1945-2005

101

Christmas Carol as a Source of Inspiration in the Works

of Polish Composers in 1945-2005

180

Dominika Sergiej

Doświadczenie krzywdy w życiu i twórczości Józefa Szajny

The Experience of Injustice in the Life and Work of Józef Szajna

RenATA GozDECKA

Fado - głos Portugalii

203

Fado - the Voice of Portugal

235

Renata GozDECKa

Miejsca ojczyste w muzyce kompozytorów hiszpańskich

XIX-XX wieku. Propozycja dydaktyczna

Native Places in the Music of Spanish Composers

of the 19th-20th centuries. A Didactic Suggestion

250

Maciej Gallas

Relacja mistrz - uczeń: coaching czy mentoring?

253

Master-Student Relations, coaching or mentoring

271

TOMASZ JASIŃSKI

Muzyka obrazu. Impresja na temat Riepina

273

The Music of a Picture. Impressions on Repin

Renata Gozdecka, Tomasz Jasiński

Bibliografia czasopisma „Annales Universitatis Mariae

Curie-Skłodowska, Sectio L, Artes”. 2003-2018

Bibliography of the Journal "Annales Universitatis Mariae

Curie-Skłodowska, Sectio L, Artes”. 2003-2018 